Original article

\title{
The relationship between nurse self-efficacy and the culture of patient safety incident reporting in a district general hospital, Indonesia
}

\author{
Wahyuni Harsul $^{\mathrm{a}, \mathrm{b}}$, Andi Masyitha Irwan ${ }^{\mathrm{c}, *}$, Elly Lilianty Sjattar ${ }^{\mathrm{d}}$ \\ ${ }^{a}$ Student of Nursing Postgraduate Program, Faculty of Nursing, Hasanuddin University, Indonesia \\ ${ }^{\mathrm{b}}$ Nurse of Syech Yusuf District General Hospital, Gowa, Indonesia \\ ${ }^{\mathrm{c}}$ Lecturer of Departement of Gerontological Nursing, Faculty of Nursing, Hasanuddin University, Indonesia \\ ${ }^{\mathrm{d}}$ Lecturer of Departement of Medical Surgical Nursing, Faculty of Nursing, Hasanuddin University, Indonesia
}

\section{A R T I C L E I N F O}

\section{Keywords:}

Nurse

Self-efficacy

Culture

Patient safety incident reporting

\begin{abstract}
A B S T R A C T
Background: The patient safety incidence reporting in Indonesia has still not been generally practised. We suggest that the culture of patient safety incident reporting in hospitals has a correlation with the self-efficacy of nurses. A nurse with strong self-efficacy may be able to convince herself that incident reporting is a good practice to maintain and to improve the quality and safety of patients in hospitals. Incident reporting can promote the importance of reporting errors and become the beginning of the learning process to prevent the occurrence of the same incident in the future. The aim of this study was to analyze the relationship of self-efficacy with the culture of patient safety incident reporting in hospitals.

Methods: This study was a descriptive correlation study which involved 100 nurses from a District General Hospital in South Sulawesi Province, Indonesia. General Self-Efficacy was used to measure the respondent selfefficacy and Hospital Survey of Patient Safety Culture instrument was used to measure the culture of patient safety incident reporting among respondents. Data were analyzed using computer statistical software.

Results: Self-efficacy was not statistically correlated with the culture of patient safety incident reporting $(\mathrm{p}=0.116)$.

Conclusion: Patient safety incident reporting is important to improve the hospital service system. The support from top leaders and hospital management by implementing the no blame policy and giving rewards and constructive feedback on patient safety incident reporting can help and facilitate nurses in applying the culture of patient safety incident reporting.
\end{abstract}

\section{Introduction}

Patient safety is currently an important issue and continues to be promoted in the health services. This is supported by the increasing demand for health services based on patient safety which will ultimately affect the image of the hospital itself.

Based on the Patient Safety Incident Reporting (PSIR), by the National Reporting and Learning System (NRLS) in the UK, in 2015, 825.416 incidents were reported in six-month period. It was $6 \%$ higher than the reported incident in the previous year. In 2016, the National Patient Safety Agency reported the incidence of patient safety in the UK as many as 1879.822 incidents. As a comparison, in Southeast Asian countries such as Malaysia, according to the Ministry of Health of Malaysia, it was reported in 2013 that the patient safety incidence number was 2.769 incidents. ${ }^{2,3}$

The incidence of patient safety (IPS) in Indonesia was monitored from 2006 to 2011; the Hospital Patient Safety Committee reported 877 incidents. ${ }^{3}$ Based on Hospital Patient Safety Committee reports from January 2010 to April 2011, the various types of reported events recorded $8.76 \%$ resulting in deaths, $2.19 \%$ permanent injuries, $21.17 \%$ temporary injuries, and $19.71 \%$ minor injuries. ${ }^{4}$

Carson, Hibbert, Williams, et $\mathrm{al}^{5}$ have identified in terms of reporting culture in England and Wales. They found that two-thirds of the reports stated that no explanation in detail could be proposed about why the incident could occur. Most errors cause damage to patients and half of the total incident reports (996) cause serious injury or death.

In reporting the errors that have been made, the involvement of selfefficacy is required. Self-efficacy is a person's self-confidence that one is able to do and perform tasks or duties properly in accordance with what is expected to achieve certain goal. ${ }^{6}$ Someone with high self-efficacy has confidence in his ability to deal with problems and is able to motivate himself, control emotion and persevere in facing difficult

\footnotetext{
* Corresponding author. Faculty of Nursing, Hasanuddin University, Jl. Perintis Kemerdekaan KM.10, Tamalanrea, Makassar, 90245, Indonesia.

E-mail address: citha_ners@med.unhas.ac.id (A.M. Irwan).
} 
situation. $^{6,7}$

For patients, self-efficacy is a critical driver to implement healthenhanced behavior. ${ }^{8}$ As for nurses, those with strong self-efficacy have the capacity to convince themselves that reporting errors is a good practice to maintain and to improve the quality and safety of patients in the hospital. ${ }^{4,9}$ It is important for a nurse to always recognize the errors that occur in order to monitor the negative impact of the errors. Efforts to recognize and report errors can be conducted through a reporting system. ${ }^{10}$ However, very limited studies exploring the relationship between self-efficacy and patient safety incidence reporting among Indonesian nurses. Understanding the relationship between these two variables might help to motivate nurses in reporting patient safety incidence. Therefore the purpose of this study was to determine the relationship between nurses' self-efficacy and patient safety incidence reporting in hospitals.

\section{Materials and methods}

\subsection{Study design and setting}

This study is a cross-sectional study which was conducted in 2018 at a District General Hospital, South Sulawesi Province, Indonesia.

\subsection{Participants and samples}

Participants in this study were 100 out of 136 executive nurses who worked in the inpatient care rooms. To estimate the sample size, the formula developed by Isaac and Michael was used. ${ }^{11}$ The confidence level was $95 \%$ and the proportion of sampling errors was $5 \%$.The inclusion criteria were nurses with government employee status, had been working in the hospital for at least 1 year, and agreed to participate in this study.

\subsection{Data management}

This study used questionnaires as data collection tools. The questionnaires consist of three main parts, demographic information, selfefficacy, and culture of patient safety incidence reporting. The questionnaires also include the frequency of event reporting, feedback, and communication about errors. General Self-Efficacy questionnaire was used to measure nurses' self-efficacy. This questionnaire consists of 10 statement items. Each answer uses a Likert scale from 1 to 4 (1 for strongly disagree, 2 for disagree, 3 for agree, and 4 for strongly agree). The Cronbach's alphas value for the General Self-Efficacy questionnaire is $0.76-0.90 .^{12}$

The Hospital Survey on Patient Safety Culture (HSOPSC) which developed by Olsen and Aase ${ }^{13}$ was used to measure the culture of IPS reporting by nurses. The researcher tested the reliability of the questionnaire based on research needs with Cronbach alpha value 0.889 . This questionnaire consists of 3 items of questions, the frequency of the event reporting, feedback, and communication about the errors. For the frequency of event reporting, the Likert scale is set from 1 to 5 [1 for never (no reporting), 2 for sometimes (1-5 reported events), 3 for frequent (6-10 reported events), 4 for always (11-20 reported events), 5 for every occurrence (21 reported events)]. The feedback and communication about errors were assessed using the Likert scale 1 to 5 ( 1 for strongly disagree, 2 for disagree, 3 for sometimes, 4 for agree, 5 for strongly agree). Demographic data is analyzed using descriptive statistics. For relationship analysis, the chi-square test was used with a significant value of $\alpha<0.05$.

\subsection{Ethical consideration}

Ethical research permission was obtained from the Hasanuddin University Health Research Ethics Committee. Research code of ethics
Table 1

Characteristic distribution of respondents $(n=100)$.

\begin{tabular}{lll}
\hline Variable & $\mathrm{N}$ & $\%$ \\
\hline $\begin{array}{l}\text { Age (mean (SD)) } \\
\text { Gender }\end{array}$ & $36.78(6.250)$ & \\
$\quad$ Male & 26 & 26 \\
$\quad$ Female & 74 & 74 \\
Education & 1 & \\
$\quad$ High School of Nursing & 17 & 1 \\
$\quad$ Diploma & 82 & 17 \\
Bachelor/RN & & 82 \\
Length of work (year/s) & 5 & 5 \\
$\quad<5$ & 56 & 56 \\
5-10 & 39 & 39 \\
$\quad>10$ & & \\
Training (IPS) & 33 & 33 \\
Yes & 67 & 67 \\
Never & & \\
\hline
\end{tabular}

number: 354/H4.8.4.5.31/PP36-COMETIC/2018. All respondents were given information about the study and provided informed consent before filling out the questionnaire.

\section{Results}

According to the characteristics of respondents (Table 1), the average age of respondents is 37 years old (mean 36.78 ), and $74 \%$ of them are female. Based on the education level, the majority of the respondents has completed Bachelor of Nursing and Registered Nursing education. More than half of the respondents have been working for 5-10 years in the hospital. Two-third of the respondents never attended IPS training (67\%) before.

The majority of respondents have low self-efficacy (90\%) (Table 3). However, $29 \%$ of respondents say rather agree that there are no difficulties in intention and purpose to report the IPS and $22 \%$ of respondents feel calm in facing difficulties. In addition, only $9 \%$ of respondents continued their goals in reporting errors even though someone was hampering them (Table 2).

The frequency of event reporting reported by nurses within 1 year is mostly Near Injury Events (48\%) with 1-5 reporting events. Moreover, $57 \%$ of feedback and communication about errors received by nurses based on incident reports was given information regarding the incident that had occurred in the work unit (Table 4).

The percentage of good IPS reporting by nurses is only $30 \%$. More than half of the respondents (53\%) have less frequency of event reporting and $60 \%$ said that the feedback given in reporting the IPS is good (Table 5).

In Table 6, shows that among respondents characteristics variables, only age has significant relationship with the culture of reporting IPS $(\mathrm{p}=0.024)$. Table 7 shows that self-efficacy has no relationship with the culture of reporting IPS ( $p=0.116$ ). There are $28 \%$ of nurses have low self-efficacy but have a good IPS reporting culture. Based on Table $8,7 \%$ of nurses has high self-efficacy, but the frequency of event reporting is less. Half of the respondents (52\%) have low self-efficacy but feedback and communication about errors are good.

\section{Discussion}

The purpose of this study was to look at the relationship between self-efficacy and the culture of IPS reporting. This study found that nurses' self-efficacy was not related to the culture of IPS reporting in hospitals. It may be caused by fact that the majority of nurses have low self-efficacy. To achieve a better patient safety system, self-efficacy is needed in nurses, because in improving patient safety, it is necessary to develop awareness of nursing staffs about the importance of patient 
Table 2

Nurses self-efficacy $(\mathrm{n}=100)$.

\begin{tabular}{|c|c|c|c|c|}
\hline \multirow[t]{2}{*}{ Variable } & Disagree & Rather & Almost & Strongly Agree \\
\hline & $\mathrm{n}(\%)$ & $\mathrm{n}(\%)$ & $\mathrm{n}(\%)$ & $\mathrm{n}(\%)$ \\
\hline Successfully solved the problem if trying & $0(0)$ & $1(1)$ & $83(83)$ & $16(16)$ \\
\hline Keep on going & $2(2)$ & $14(14)$ & $75(75)$ & $9(9)$ \\
\hline There are no difficulties in carrying out intentions and goals & $0(0)$ & 29 (29) & $68(68)$ & $3(3)$ \\
\hline Knowing how to behave & $1(1)$ & $6(6)$ & $85(85)$ & $8(8)$ \\
\hline Knowing how to deal with problems & $0(0)$ & $6(6)$ & $88(88)$ & $6(6)$ \\
\hline Have a solution to every problem & $0(0)$ & $12(12)$ & $87(87)$ & $1(1)$ \\
\hline Calm in the face of difficulties & $0(0)$ & $22(22)$ & $72(72)$ & $6(6)$ \\
\hline Have lots of ideas to solve problems & $0(0)$ & $17(17)$ & 77 (77) & $6(6)$ \\
\hline Able to handle unexpected incident & $0(0)$ & $14(14)$ & $84(84)$ & $2(2)$ \\
\hline Ready to handle every incident & $0(0)$ & $7(7)$ & 79 (79) & $14(14)$ \\
\hline
\end{tabular}

Table 3

Distribution category: self-efficacy $(n=100)$.

\begin{tabular}{llc}
\hline Self-efficacy & $\mathrm{N}$ & $(\%)$ \\
\hline High & 10 & 10 \\
Low & 90 & 90 \\
\hline
\end{tabular}

safety by developing hospital policies related to the roles and responsibilities of each staff/individual if an incident occurred. ${ }^{14}$

According to Bandura, ${ }^{15}$ self-efficacy is a feeling of confidence of a person on his/her ability to take actions, good or bad, right or wrong, able or not as expected. Personal beliefs about self-efficacy can influence a person's behaviour, ways of thinking, and emotional reactions in difficult situations. ${ }^{16}$ Based on research conducted by Lee, Yang and Chen, ${ }^{17}$ self-efficacy is able to influence behavioral control perceived by nurses, so that it can foster the intention of nurses to report errors that occur during the provision of health services.

In this study, it was found that although the majority of nurses had low self-efficacy, they had good cultures of IPS reporting. This can be caused by respondents in this study have the status of government employees who have an obligation to take duties and responsibilities in accordance with applicable rules. In addition, nurses who have high selfefficacy, but lack of incident reporting behavior, are nurses who feel they have difficulties in carrying out their intention and goal of reporting IPS. Furthermore, only a small proportion of nurses will continue their goals to report errors even though there is someone who is hindering them from doing that. The finding is in line with a study conducted by Hung et al, that nursing manager and colleagues attitudes are the main predictor which affected whether a nurse reported medical error or not. ${ }^{18}$

The lack of nurses who have participated in training in IPS reporting at the Hospital can be one factor in the lack of knowledge related to the
Table 5

Culture of reporting patient safety incidents $(n=100)$.

\begin{tabular}{lll}
\hline The culture of Reporting Patient Safety Incidents & $\mathrm{n}$ & $(\%)$ \\
\hline The frequency of Event Reporting & & \\
$\quad$ Good & 14 & 14 \\
$\quad$ Moderate & 33 & 33 \\
$\quad$ Less & 53 & 53 \\
Feedback and Communication About Error & & \\
$\quad$ Good & 60 & 60 \\
Moderate & 38 & 38 \\
Less & 2 & 2 \\
Overall & & 30 \\
Good & 30 & 51 \\
Moderate & 51 & 19 \\
Less & 19 & \\
\hline
\end{tabular}

reporting of IPS which causes a lack of IPS reporting. Some studies found that lack of knowledge is one factor of low intention to report incidence. In addition, some individuals considered that it is better to correct the error instead of reporting it. ${ }^{19,20}$

From this study it was found that only $14 \%$ of nurses felt very ready to handle every event that occurred when reporting an incident. This shows that there are still nurses who do not report because they feel they are not ready to handle things that might occur if they report an incident. The fear of being blamed, fear of receiving punishment, legal consequences and workplace discrimination are obstacles in reporting patient safety incidents. ${ }^{21}$ In addition, the fear felt by health workers was a significant reason in reporting the IPS. ${ }^{22}$ Lin \& Ma said that the high demands on nurses to realize the purpose of hospitals in improving quality, consequently nurses sometimes choose not to report incidents to avoid being blamed by superiors as a barrier to achieving hospital goals. $^{23}$

Table 4

The culture of Reporting Patient Safety Incidents $(n=100)$.

\begin{tabular}{|c|c|c|c|c|c|}
\hline \multirow[t]{3}{*}{ Variable } & \multicolumn{5}{|c|}{ The frequency of event reporting } \\
\hline & Never & Sometimes & Often & Always & occurrences \\
\hline & n (\%) & n (\%) & n (\%) & n (\%) & n (\%) \\
\hline Nearly Injured Event & $5(5)$ & $48(48)$ & $27(27)$ & $9(9)$ & $11(11)$ \\
\hline Potential Injury Events & $13(13)$ & 39 (39) & $31(31)$ & $11(11)$ & $6(6)$ \\
\hline \multirow[t]{3}{*}{ Unexpected Events } & $18(18)$ & $33(33)$ & $28(28)$ & $12(12)$ & $9(9)$ \\
\hline & \multicolumn{5}{|c|}{ Feedback and communication about error } \\
\hline & $\begin{array}{l}\text { Strongly disagreed } \\
\text { n (\%) }\end{array}$ & $\begin{array}{l}\text { Disagree } \\
\text { n (\%) }\end{array}$ & $\begin{array}{l}\text { Sometimes } \\
\text { n (\%) }\end{array}$ & $\begin{array}{l}\text { Agree } \\
\text { n (\%) }\end{array}$ & $\begin{array}{l}\text { Strongly agree } \\
\text { n (\%) }\end{array}$ \\
\hline Feedback & $2^{2}$ & $1^{1}$ & $38(38)$ & $53(53)$ & $6^{6}$ \\
\hline Given information & $2^{2}$ & $0(0)$ & $23^{23}$ & $57(57)$ & $18^{18}$ \\
\hline Discuss of prevention & $0(0)$ & $2^{2}$ & $23^{23}$ & $37(37)$ & $38(38)$ \\
\hline
\end{tabular}


Table 6

Relationship characteristic respondents and culture of patient safety incident reporting $(\mathrm{n}=100)$.

\begin{tabular}{|c|c|c|c|c|}
\hline \multirow[t]{3}{*}{ Variable } & \multicolumn{3}{|c|}{ Culture of Patient Safety Incident Reporting } & \multirow[t]{3}{*}{$p$} \\
\hline & Good & Moderate & Less & \\
\hline & n (\%) & $\mathrm{n}(\%)$ & n (\%) & \\
\hline \multicolumn{5}{|l|}{ Age } \\
\hline $26-35$ & $23(48.9)$ & $15(31.9)$ & $9(19.1)$ & $0.024^{\mathrm{a}}$ \\
\hline $36-45$ & $5(12)$ & $29(69)$ & $8(19)$ & \\
\hline $45-55$ & $2(18.2)$ & $7(63.6)$ & $2(18.2)$ & \\
\hline \multicolumn{5}{|l|}{ Gender } \\
\hline Male & $8(30.8)$ & $10(38.5)$ & $8(30.8)$ & $0.161^{\mathrm{b}}$ \\
\hline Female & $22(29.7)$ & $41(55.4)$ & $11(14.9)$ & \\
\hline \multicolumn{5}{|l|}{ Education } \\
\hline $\begin{array}{l}\text { High School of } \\
\text { Nursing }\end{array}$ & $23(28)$ & $44(53.7)$ & $15(18.3)$ & $0.866^{\mathrm{a}}$ \\
\hline Diploma & $7(41.2)$ & $6(35.3)$ & $4(23.5)$ & \\
\hline Bachelor/RN & $0(0)$ & $1(100)$ & $0(0)$ & \\
\hline \multicolumn{5}{|l|}{ Years of Service } \\
\hline$<5$ & $3(60)$ & $2(40)$ & $0(0)$ & $0.155^{\mathrm{a}}$ \\
\hline $5-10$ & $19(33.9)$ & $26(46.4)$ & $11(19.6)$ & \\
\hline$>10$ & $8(20.5)$ & $23(59)$ & $8(20.5)$ & \\
\hline \multicolumn{5}{|l|}{ Training (IPS) } \\
\hline Yes & $10(30.3)$ & $19(57.6)$ & $4(12.1)$ & $0.439^{\mathrm{b}}$ \\
\hline No & $20(29.9)$ & $32(47.8)$ & $15(22.4)$ & \\
\hline
\end{tabular}

a Kruskal-Wallis.

b Chi square.

Table 7

Relationship between self-efficacy and culture of patient safety incident reporting $(\mathrm{n}=100)$.

\begin{tabular}{|c|c|c|c|c|}
\hline \multirow[t]{3}{*}{ Variable } & \multicolumn{3}{|c|}{ The culture of Patient Safety Incident Reporting } & \multirow[t]{3}{*}{$p$} \\
\hline & Good & Moderate & Less & \\
\hline & n (\%) & n (\%) & n (\%) & \\
\hline \multicolumn{5}{|c|}{ Self-efficacy } \\
\hline High & $2(2)$ & $8(8)$ & $0(0)$ & $0.116^{\mathrm{a}}$ \\
\hline Low & $28(28)$ & $43(43)$ & 19 (19) & \\
\hline
\end{tabular}

a Chi-Square test.

Table 8

Relationship between self-efficacy and sub variable culture of patient safety incident reporting $(n=100)$.

\begin{tabular}{|c|c|c|c|c|c|c|c|c|}
\hline \multirow[t]{4}{*}{ Variable } & \multicolumn{8}{|c|}{ The culture of Patient Safety Incident Reporting } \\
\hline & \multicolumn{3}{|c|}{$\begin{array}{l}\text { The frequency of event } \\
\text { reporting }\end{array}$} & \multirow[t]{2}{*}{$\mathrm{p}$} & \multicolumn{3}{|c|}{$\begin{array}{l}\text { Feedback and } \\
\text { communication about } \\
\text { error }\end{array}$} & $\mathrm{p}$ \\
\hline & Good & Moderate & Less & & Good & Moderate & Less & \\
\hline & $\mathrm{n}(\%)$ & n (\%) & $\begin{array}{l}\mathrm{n} \\
(\%)\end{array}$ & & $\mathrm{n}(\%)$ & $\mathrm{n}(\%)$ & $\begin{array}{l}\mathrm{n} \\
(\%)\end{array}$ & \\
\hline
\end{tabular}

\begin{tabular}{rllllllll}
\hline \multicolumn{2}{l}{ Self-efficacy } \\
High & $1(1)$ & $2(2)$ & 7 & $0.522^{\text {a }}$ & $8(8)$ & $2(2)$ & 0 & $0.385^{\text {a }}$ \\
& & & $(7)$ & & & & $(0)$ & \\
Low & 13 & $31(31)$ & 46 & 52 & $36(36)$ & 2 & \\
& $(13)$ & & $(46)$ & $(52)$ & & $(2)$ & \\
\hline
\end{tabular}

a Chi-Square test.

Therefore, it needs special attention for management to apply the no blame principle so that nurses in reporting IPS do not feel afraid of being blamed and considered incompetent by their colleagues. In addition, the reward system can also be used as a motivation for nurses to always report the IPS that occurs in health services. According to Chartey, ${ }^{21}$ nurses must have the confidence to report every incident that occurs voluntarily to the manager or supervisor by applying the no blame principle, not giving penalties to those who report errors and provide constructive feedback from reported incidents. Thus, the IPS reporting process will become easier.

The lack of nurse participation in IPS reporting training at the Hospital can be one factor in the lack of knowledge related to the importance of IPS reporting. This is in line with the study conducted by Harsul, Syahrul and Madjid ${ }^{24}$ who said that no dissemination related to IPS reporting, lack of development of nurses skills and knowledge, lack of nurse compliance in reporting IPS, and the inadequacy of facilities and infrastructure are obstacles faced in implementing the IPS reporting culture so that the number of unexpected events that occur at the hospital are not reported.

Some nurses who have participated in the training claim that they have not understood the systematic reporting of IPS according to the system and reporting format because there are too many details to be memorized and understood. This can be an evaluation for the hospital, especially for the nursing management to always update nurses' knowledge and skills in reporting the IPS. Jansma, Wagner, Kate and Bijnen $^{25}$ stated that after taking the training twice, it was found that 25 respondents (57\%) experienced a positive change in the knowledge, skills and attitudes taken after the training. Patient safety training has a long-term positive effect on knowledge, skills and attitudes, and influences incident reporting behaviour.

By reporting, there will be a learning process that will change the health care system to prevent the similar incidents from recurring, both in the same unit and in other units. There were some limitations in this study. First, the research instrument used consists of closed statements so that it is difficult to explore the data more deeply in relation to the reasons and opinions of respondents based on the answers given. Second, the design of the study was carried out with a cross-sectional approach within a certain period of time using only one measurement so that the research design used was still weak and it was difficult to observe the direct causes that affect self-efficacy and lack of patient safety incidence reporting. Third, instrument used to measure nurses' self-efficacy is not specifically aimed to determine efficacy in reporting patient safety incident. Therefore, a more specific instrument to measure self-efficacy of nursing in reporting patient safety incident is needed for further study.

\section{Conclusion}

Self-efficacy was not statistically correlated with the culture of patient safety incident reporting. Patient safety incident reporting culture is crucial to improve the hospital service quality. Therefore, support from leader and hospital management by practicing the no blame policy and providing rewards and constructive response on patients safety incident reporting could help and facilitating nurses in implementing patient safety incident reporting culture.

\section{Authors' contributions}

WH, AMI, and ELS conceived the study design. WH, AMI, ELS performed data collection and analysis. WH and AMI wrote the manuscript.

\section{Funding}

This study did not receive any specific grant.

\section{Declaration of competing interest}

The authors declare no competing interests in this study. 


\section{Acknowledgements}

The authors would like to acknowledge the contribution of study participants.

\section{References}

1. Puspitasari M. Merumuskan learning organization melalui analisis budaya keselamatan pasien dan budaya organisasi di RS. Masmitra; 2015.

2. NHS England. Patient Safety Incident Reporting Continues to Improve. England: Author. 2015; 2015.

3. RSUDZA. Pentingnya pelaporan insiden keselamatan pasien di rumah sakit. Aceh: RSUDZA. 29 December 2017https://rsudza.acehprov.go.id/tabloid/2017/12/29/ pentingnya-pelaporan-insiden-keselamatan-pasien-di-rumah-sakit/.

4. Komite Keselamatan Pasien Rumah Sakit. Pedoman Pelaporan Insiden Keselamatan Pasien (IKP). Jakarta: KKPRS; 2015.

5. Carson SA, Hibbert P, Williams $\mathrm{H}$, et al. Characteristing the nature of primary care patient safety incident reports in the England and Wales National Reporting and Learning System: a mixed-methods agenda-setting study for general practice. Health Serv Res. 2016;4(27).

6. Bandura A. Self-efficacy: toward a unifying theory of behavioral change. Psychol Rev. 1977;84(2):191-215.

7. Luszczynska A, Dona BG, Schwarzer R. General self-efficacy in various domains of human functioning: evidence from five countries. Int. J. Hisp. Psychol. 2005;40(2):80-89. https://doi.org/10.1080/00207590444000041.

8. Irwan AM, Kato M, Kitaoka K, Kido T, Taniguchi Y, Shogenji M. Self-care practices and health-seeking behavior among older persons in a developing country: theoriesbased research. Int J Nurs Sci. 2016;3:11-23.

9. Alimohammadzadeh K, Joladi SE, Olya M, Ghaiyoomi A. A comparative study on effective factors in patient safety culture from the nursing staff points of view. $J$ Health Manag Inf. 2016;4(2):57-61.

10. Zacher H. Patient Safety - A Psychological Perspective. Berlin: Walter de Gruyter GmbH; 2014.

11. Sugiyono. Statistika Untuk Penelitian. Bandung: Alfabeta; 2017.

12. Schwarzer R, Jerusalem M. Generalized self-efficacy scale. In: Weinman J, Wright S, johnston M, eds. Measures in Health Psychology: A User's Portofolio. Causal and Control Beliefs. 1995; 1995:35-37. https://doi.org/10.1192/bjp.112.483.211-a.

13. Olsen E, Aase K. Validity and realiability of the hospital Survey on patient safety culture and exploration of longitudinal change at a hospital. Saf Sci Monit. 2009:455-485. https://doi.org/10.1017/cbo9780511978371.055.

14. Menteri Kesehatan Republik Indonesia. Peraturan Menteri Kesehatan Republik Indonesia (Cat. No. 1691). Jakarta, Indonesia: MKRI; 2011.

15. Bandura A. Self-Efficacy: The Exercise of Control. Newyork: Freeman; 1997.

16. Bandura A. Social Foundations of Thought and Action: A Social Cognitive Theory. Englewood Cliffs, NJ: Prentice Hall; 1986.

17. Lee $Y$, Yang C, Chen T. Barriers to incident-reporting behavior among nursing staff: a study based on the theory of planned behavior. J Manag Organ. 2015:1-8. https:// doi.org/10.1017/jmo.2015.8.

18. Hung CC, Chu TP, Lee BO, Hsiao CC. Nurses' attitude and intention of medication administration error reporting. J Clin Nurs. 2016;25(3-4):445-453. https://doi.org/ 10.1111/jocn.13071.

19. Heard GC, Sanderson PM, Thomas R. Barriers to adverse event and error reporting in Anesthesia. Anesth Analg. 2012;144:604-614.

20. Hughes RG, Blegen M. Medication administration safety. In: Hugges RG, ed. Patient Safety and Quality: An Evidence Based Handbook for Nurses. Rockville, MD: Agency for Healthcare Research and Quality; 2008:397-457.

21. Evans SM, Berry JG, Smith BJ, et al. Attitudes and barriers to incident reporting: a collaborative hospital study. Qual Saf Health Care. 2006;15(1):39-43. https://doi. org/10.1136/qshc.2004.012559.

22. Kreckler S, Catchpole K, Mcculloch P, Handa A. Factors influencing incident reporting in surgical care. Qual Saf Health Care. 2009:116-120. https://doi.org/10. 1136/qshc. 2008.026534 .

23. Lin Y, Ma S. Willingness of nurses to report medication administration errors in southern Taiwan : a cross-sectional Survey. Worldviews Evidence-Based Nurs. 2009;6(4):237-245.

24. Harsul W, Syahrul S, Majid A. Penerapan budaya pelaporan insiden keselamatan pasien di rumah sakit umum daerah tipe B provinsi Sulawesi selatan. Jurnal Panrita Abdi. 2018;2(2):119-126.

25. Jansma JD, Wagner C, Kate RW, Bijnen AB. Effects on incident reporting after educating residents in patient safety : a controlled study. BMC Health Serv Res. 2011;11(1):335. https://doi.org/10.1186/1472-6963-11-335. 